\title{
PENGARUH MODEL PEMBELAJARAN KOOPERATIF \\ TIPE TIME TOKEN BERBANTU PUZZLE TERHADAP \\ KEMAMPUAN BERPIKIR KRITIS PESERTA DIDIK KELAS X PADA MATERI GELOMBANG
}

\author{
Sri Latifah \\ Program Studi Pendidikan Fisika, FTK IAIN Raden Intan Lampung; E-mail: Srilatifah21@ yahoo.com
}

\begin{abstract}
The purpose in this research is to know the influence of cooperative Learning Models Time Type Token with puzzle toward critical thought abilityof the students grade X on Wave material at MA Al Hikmah Bandar Lampung year2014/2015 This research is quantitative with quasi experiment. Reasearch design that used is Nonequivalent Control Group Design with the population of all the students in grade X semestre even at MA Al Hikmah, Bandar Lampung year 2014/2015. The Sample of this research are used 2 classes; experiment and control class, where as experiment class (XA) used cooperative time type token model with puzzle and control class $(X B)$ used cooperative learning model with pictures as media. Data colecting is using test (pretest and posttest), observation and documentation. After the data test collected, then it is analyzed by using normality test of statistic analysis, homoginity test and test-t. According to the result, it can be concluded that time type token with puzzle application influence significantly ttoward the ability of critical thinking of the students on Wave material at MA Al Hikmah Bandar Lampung year 2014/2015.
\end{abstract}

\begin{abstract}
Abstrak: Tujuan penelitian ini adalah untuk mengetahui pengaruh model pembelajaran kooperatif tipe time token berbantu puzzle terhadap kemampuan berpikir kritis peserta didik kelas X pada materi Gelombang di MA Al Hikmah Bandar Lampung Tahun Pelajaran 2014/2015 .Penelitian ini termasuk kedalam penelitian kuantitatif dengan jenis penelitian Quasi Eksperimen. Desain penelitian ini menggunakan Nonequivalent Control Group Design dengan populasi yaitu seluruh peserta didik kelas X semester genap di MA Al Hikmah Bandar Lampung T.P 2014/2015. Sampel penelitian ini menggunakan 2 kelas yaitu kelas eksperimen dan kontrol, dimana kelas eksperimen (XA) menggunakan model kooperatif tipe time token berbantu puzzle dan kelas kontrol (XB) menggunakan model pembelajaran kooperatif media gambar. Teknik pengambilan data menggunakan test (pretest dan posttest), observasi dan dokumentasi. Setelah data test dikumpulkan kemudian akan dianalisis menggunakan analisis statistik dengan menggunakan uji normalitas, uji homogenitas dan uji-t. Berdasarkan hasil penelitian dapat disimpulkan bahwa penggunaan model time token berbantu puzzle berpengaruh secara signifikan terhadap kemampuan berpikir kritis peserta didik pada materi Gelombang di MA Al Hikmah Bandar Lampung Tahun Pelajaran 2014/2015
\end{abstract}

Kata kunci: gelombang, kemampuan berpikir kitis, model pembelajaran time token berbantu puzzle. 


\section{PENDAHULUAN}

Perkembangan ilmu pengetahuan dan teknologi telah membawa perubahan dalam berbagai aspek kehidupan manusia. Dimana berbagai permasalahan hanya dapat diselesaikan dengan upaya penguasaan serta peningkatan ilmu pengetahauan dan teknologi. Oleh karena itu, mutu pendidikan harus ditingkatkan guna meningkatkan sumber daya manusia.

Perspektif keagaman pun memandang pendidikan merupakan kewajiban bagi setiap orang beriman agar memperoleh ilmu pengetahuan. Dengan ilmu pengetahuan seseorang akan menjadi mulia, terhormat, dan mampu menghadapi segala permasalahan yang terjadi dalam kehidupan. Banyak sekali ilmu-ilmu yang dipelajari dalam pendidikan, baik pada pendidikan dasar sampai menengah atas. Salah satunya adalah pelajaran IPA pada sekolah menengah pertama. Pembelajaran pada dasarnya merupakan upaya untuk membantu peserta didik melakukan kegiatan belajar. Tujuan pembelajaran menurut Fred Percival dan Henry Ellington dalam Hamzah B. Uno (2011) adalah suatu pernyataan yang jelas dan menunjukan penampilan atau keterampilan peserta didik tertentu yang diharapkan dapat dicapai sebagai hasil belajar.

Model pembelajaran mempunyai andil cukup besar dalam meningkatkan mutu pendidikan. Berdasarkan fakta yang ada bahwa model yang digunakan guru monoton yang membuat peserta didik merasa bosan dan tidak menyukainya. Kemampuan yang diharapkan dapat dimiliki peserta didik, akan ditentukan oleh kerelevansian penggunaan suatu model yang sesuai dengan tujuan.
Berdasarkan hasil prasurvey yang telah dilakukan di MA Al Hikmah Bandar Lampung, masalah yang muncul diketahui, bahwa banyak peserta didik yang tidak berani bertanya karena takut pertanyaan yang akan ditanyakan adalah pertanyaan yang tidak perlu ditanyakan dan dianggap sebagai peserta didik yang bodoh, dengan alasan itu mereka kesulitan dalam menyampaikan pendapat ketika ada materi yang belum mereka mengerti. Sedangkan peserta didik yang sering bertanyalah yang mendominasi kelas. Oleh sebab itu perlu adanya model pembelajaran yang mampu mengubah peserta didik untuk tampil percaya diri dalam menyampaikan pendapat mereka, salah satunya adalah model pembelajaran kooperatif tipe time token berbantu puzzle.

Menurut Miftahul Huda (2013) model pembelajaran time token merupakan model pembelajaran yang inovatif dan menyenangkan serta menuntut peserta didik untuk aktif dan kreatif. Model pembelajaran kooperatif tipe time token berbantu puzzle merupakan model pembelajaran yang bertujuan agar masing-masing anggota kelompok diskusi mendapatkan kesempatan untuk memberikan kontribusi mereka dan mendengarkan pandangan serta pemikiran anggota lain. Model ini memiliki struktur pengajaran yang sangat cocok digunakan untuk mengajarkan keterampilan sosial, serta untuk menghindari peserta didik mendominasi pembicaraan atau peserta didik diam sama sekali.

Time token berasal dari kata dalam bahasa Inggris yaitu time yang artinya waktu dan token yang artinya berbicara. Secara bahasa time token dapat diartikan sebagai waktu untuk berbicara. Model pembelajaran time token merupakan model pembelajaran yang bertujuan agar masingmasing anggota kelompok diskusi mendapatkan kesempatan untuk 
$\begin{array}{lrr}\text { memberikan } & \text { kontribusi } & \text { dalam } \\ \text { menyampaikan } & \text { pendapatnya } & \text { dan }\end{array}$ mendengarkan pandangan serta pemikiran anggota lain. Tipe pembelajaran ini dimaksudkan sebagai alternatif untuk mengajarkan keterampilan sosial yang bertujuan untuk menghindari peserta didik mendominasi atau peserta didik diam sama sekali dan menghendaki peserta didik saling membantu dalam kelompok kecil dan lebih dicirikan oleh penghargaan kooperatif daripada individu.( Aris Shoimin, 2014).

Model pembelajaran time token dipandang sebagai suatu solusi untuk mengembangkan keterampilan peserta didik dalam berkomunikasi sehingga peserta didik tidak diam atau mendominasi pembicaraan, seperti yang telah dikemukakan oleh Arends. Model Pembelajaran time token digunakan untuk melatih dan mengembangkan keterampilan sosial agar peserta didik tidak mendominasi pembicaraan atau diam sama sekali.

Selain mengembangkan model pembelajaran yang aktif, agar tercapai tujuan pembelajaran seorang guru juga harus dapat memotivasi peserta didik. Suasana pembelajaran yang menarik dan menyenangkan akan lebih memotivasi peserta didik, sehingga tercapai pembelajaran yang efektif. Salah satu cara untuk menciptakan suasana yang menyenangkan dalam kelas adalah dengan menyajikan suatu permainan. Puzzle merupakan salah satu media permainan yang sederhana dan menarik serta mudah untuk diterapkan dalam pembelajaran. Media permainan adalah permainan menyusun potongan- potongan gambar agar tercipta suatu gambar yang utuh.

Permainan puzzle dapat meningkatkan hasil belajar peserta didik dan menciptakan pembelajaran yang menyenangkan. Park dan Park dalam analisisnya menyebutkan bahwa permainan puzzle dapat meningkatkan konsentrasi, minat serta mengembangkan kecerdasan. Jenis permainan yang akan digunakan dalam penelitian ini adalah . disini adalah permainan menyusun kepingankepingan gambar sehingga terbentuk suatu gambar yang utuh. Puzzle merupakan alat peraga sederhana yang mudah dibuat tetapi sangat mengasyikkan digunakan sebagai media belajar peserta didik

Pembelajaran yang berlangsung di kelas masih belum mengoptimalkan usaha untuk mengembangkan keterampilan berpikir tingkat tinggi (higher order thinking) dalam hal ini keterampilan berpikir kritis. Selama proses pembelajaran biologi di kelas cenderung hanya mengasah aspek mengingat (remembering) dan memahami (understanding), yang merupakan low order of thinking, bahkan proses pembelajaran tersebut kurang memperhatikan aspek berpikir kritis. Rendahnya keterampilan berpikir kritis peserta didik disebabkan beberapa penyimpangan terhadap aturan yang telah ditetapkan. Salah satu bentuk penyimpangan dalam pelaksanaan pembelajaran adalah kegitan inti belum optimal atau belum memenuhi proses eksplorasi, elaborasi dan konfirmasi. Pengajaran keterampilan berpikir kritis di Indonesia memiliki beberapa kendala, salah satunya adalah dominasinya guru dalam proses pembelajaran dan tidak memberi akses pada peserta didik untuk berkembang secara mandiri melalui penemuan dan proses berpikirnya. Dalam usaha meningkatkan keterampilan berpikir kritis, diperlukan inovasi baru dalam pembelajaran yang relevan dengan keadaan peserta didik saat ini. 
Kemampuan berpikir kritis dapat ditingkatkan guru dengan pembelajaran menggunakan model pembelajaran tipe time token berbantu puzzle . Sebagaimana berpikir kritis menurut Robert Ennis merupakan berfikir secara beralasan dan reflektif dengan menekankan pada pembuatan keputusan tentang apa yang harus dipercayai dan dilakuakan dan pada akhirnya akan mengasilkan kesimpulan dan keputusan yang dapat dikomunikasikan oleh pendengar melalui model pembelajaran kooperatif tipe time token berbantu puzzle. Dengan model pembelajaran time token berbantu puzzle, pendapat peserta didik mampu tersampaikan dan didengarkan peserta didik lainya, dengan begitu mereka dapat melatih dan meningkatkan kemampuan berpikir kritis mereka.

Masih rendahnya keterampilan bepikir kritis peserta didik dapat dilihat pula dari hasil penelitian yang pernah dilakukan, oleh Tia Restiasari dkk (2015), bahwa terdapat permasalahan yang dijumpai dalam pembelajaran biologi, diantaranya yaitu pembelajaran yang diterapkan guru masih lebih dominan kepada aspek pengetahuan dan pemahaman konsep, belum menuntut peserta didik untuk aktif dan melatih peserta didik dalam berpikir serta menemukan sendiri konsep yang ada, peserta didik cenderung lebih sering menghafal konsep tanpa mengetahui bagaimana proses untuk menemukan konsep sehingga mengakibatkan kurangnya kemampuan peserta didik dalam berpikir untuk pemecahan masalah. Kemampuan berpikir kritis merupakan kompetensi yang harus dimiliki oleh peserta didik.

Berpikir keritis merupakan sebuah proses yang terarah dan jelas yang digunakan dalam kegiatan mental seperti memecahkan masalah, mengambil keputusan, membujuk, menganalisis asumsi, dan melakuakan penelitian ilmiah. Secara umum berpikir kritis berarti kemampuan untuk berpendapat dengan cara yang terorganisasi. Selain itu berpikir kritis merupakan kemampuan untuk mengevaluasi secara sistematis bobot pendapat pribadi dan pendapat orang lain. (Elaine B. Johnson, 2014).

Berdasarkan hasil wawancara dengan ibu Herlina, S.Pd sebagai guru bidang study IPA di MA Al Hikmah Bandar Lampung pada hari rabu, tanggal 21 Januari 2015, guru tersebut mengemukakan bahwa peserta didik masih rendah dalam kemampuan berpikirnya baik bertanya atau menyampaikan pendapat, sehingga berdampak pada hasil belajar peserta didik pada akhirnya. Sebagaimana Kriteria Ketuntasan Minimal (KKM) untuk pelajaran IPA di MA Al Hikmah Bandar Lampung adalah 70 .

Rendahnya kemampuan berpikir kritis ditandai dengan masih sulitnya peserta didik untuk memberikan penjelasan yang sederhana, membangun keterampilan dasar, menyimpulkan, memberi penjelasan lanjut dan mengatur strategi dan teknik dalam proses belajar mengajar. Kurikulum 2006 yang dikenal Kurikulum Tingkat Satuan Pendidikan (KTSP) memasukkan keterampilan-keterampilan berpikir yang harus dikuasai anak disamping materi isi yang merupakan pemahaman konsep, Dengan berpikir kritis peserta didik dapat meningkatkan kreativitas mereka sehingga hasil belajar pun akan ikut meningkat, karena Untuk menunjuk pada pengaturan kegiatan kognitif dapat digunakan metagonition, yaitu pengetahuan tentang kegiatan berpikir dan belajar serta kontrol 
terhadap kegiatan itu pada diri sendiri. (Djaali, 2008).

Selain itu berdasarkan informasi dari guru mata pelajaran IPA bahwa model pembelajaran time token berbantu puzzle belum pernah diterapkan di sekolah ini sehingga peneliti mencoba meneliti model pembelajaran tersebut dengan tujuan untuk meningkatkan kemampuan berpikir kritis peserta didik. Dengan demikian, diharapkan peserta didik terbiasa untuk berpikir kritis, dengan berani mengajukan pertanyaan, mengajukan pendapat, dan mampu mengerjakan tugas yang diberiakan oleh guru. Selanjutnya, peserta didik akan menemukan makna dari pembelajaran itu sendiri.

\section{METODE PENELITIAN}

Jenis penelitian ini adalah penelitian Quasi Eksperimen. Desain penelitian menggunakan Nonequivalent Control Group Design. Desain ini hampir sama dengan pretest-posttest control group design, hanya pada desain ini kelompok eksperimen maupun kelompok kontrol tidak dipilih secara random. Variabel bebas dalam penelitian ini adalah model pembelajaran time token berbantu puzzle , sedangkan variabel terikat adalah kemampuan berpikir kritis peserta didik. Populasi dalam penelitian ini adalah seluruh peserta didik kelas X semester genap di MA Al Hikmah Bandar Lampung Tahun Pelajaran 2014/2015 yaitu 364 peserta didik, yang terdiri dari 14 kelas. Sedangkan Sampel yang diambil dalam penelitian ini terdiri dari 2 kelas, yaitu kelas X.A (27 peserta didik) sebagai kelas eksperimen yang diberi perlakuan model pembelajaran time token berbantu puzzle dan X.B (27 peserta didik) sebagai kelas kontrol dengan model pembelajaran kooperatif media gambar. Teknik pengambilan sampel pada penelitain ini dilakukan dengan cara Purposive sampling yang merupakan cara atau teknik pengambilan sampel yang ditetapkan secara sengaja oleh peneliti atas dasar kriteria atau pertimbangan tertentu yaitu kelas yang diajar oleh guru yang sama dan yang memiliki keadaan rata-rata yang hampir sama dan setara. Adapun teknik pengumpulan data pada penelitian ini melalui test (pretest -posttest), observasi dan dokumentasi.

Sebelum soal pretest dan posttest digunakan pada kelas eksperimen dan kontrol, terlebih dahulu dilakukan uji coba tes kemampuan berpikir kritis yang terdiri dari 20 butir soal uraian pada peserta didik diluar sampel penelitian. Uji coba tes dilakukan pada 30 peserta didik kelas XI.D MA Al Hikmah Bandar Lampung. Uji coba instrument tersebut bertujuan untuk mengetahui apakah instrumen tersebut memiliki validitas, reliabilitas, tingkat kesukaran dan daya beda soal yang tinggi, karena soal yang baik adalah soal yang memenuhi syarat kriteria dari uji validitas, uji reliabilitas, uji taraf kesukaran dan uji daya beda. Berdasarkan hasil perhitungan dari 20 soal yang telah diuji cobakan, diperoleh hasil 10 butir soal yang dinyatakan valid dan 10 diantaranya memilki validitas yang rendah atau dapat dikatakan tidak valid. Soal yang telah di validasi menggunkan program ANATES dengan nilai $\alpha=0,05$. Soal yang telah valid tersebut akan digunakan untuk soal pretest dan postest dalam penelitian sebanyak 10 butir soal uraian kemampuan berpikir kritis. Pada saat uji reliabilitas menggunakan program ANATES, soal-soal yang valid 
memiliki koefisien reliabilitas dalam penelitian sebesar 0,71 termasuk katagori tinggi, hal ini menyatakan bahwa soal-soal yang akan diujikan reliabel, karena soal yang dikatakan reliabel apabila koefisien reliabilitasnya $>$ dari 0,70

Berdasarkan uji tingkat kesukaran rata-rata butir soal menunjukkan bahwa hasil uji tingkat kesukaran dari 20 soal dihasilkan 1 soal berkriteria mudah dan 19 soal berkriteria sedang sedangkan untuk soal yang berkriteria sukar tidak ditemukan. Berdasarkan hasil perhitungan terhadap jawaban peserta didik diperoleh daya pembeda soal yang beragam, Berdasarkan perhitungan menggunakan program ANATES uji daya pembeda, menunjukan dari 20 soal diperoleh1 butir soal yang memiliki daya beda lebih dari 0,71, sehingga daya beda berkriteria sangat baik, didapat pula sejumlah 9 soal yang mempunyai tingkat diskriminasi dari 0,41 sampai 0,70 dan dikatakan daya beda berkriteria baik. 2 soal yang berkriteria cukup, ini berarti soal dapat diperbaiki atau dibuang, sedangkan 8 soal berkriteria ditolak atau jelek, maka butir soal tersebut dibuang. Dari 12 butir soal yang diterima hanya 10 yang layak digunakan untuk mengambil data tes kemampuan berpikir kritis pesrta didik, karena soal nomor 12 dan 17 merupakan soal yang tidak valid. Teknik analisis data yaitu uji normalitas dengan menggunakan uji liliefors dan uji homogenitas menggunakan uji fisher. Hipotesis dalam penelitian ini menggunakan uji-t independent. Semua uji ini dilakukan dengan menggunakan program Microsoft Excel.

\section{HASIL DAN PEMBAHASAN}

\section{Data Hasil Kemampuan Berpikir Kritis}

Pengambilan data dilakukan dalam tiga kali pertemuan. Pada pertemuan tersebut dilakukan pengambilan data menggunakan soal kemampuan berpikir kritis dalam bentuk uraian. Hasil penelitian yang dapat dijadikan data untuk mengetahui tingkat keberhasilan kemampuan berpikir kritis peserta didik dalam kegiatan belajar mengajar yaitu dengan adanya pretest dan postest, lembar kerja peserta didik dalam bentuk kelompok. Berikut tabel hasil kemampuan berpikir kritis peserta didik kelas eksperimen dan kelas kontrol.

Tabel 1. Kemampuan berpikir kritis peserta didik kelas eksperimen dan kontrol MA Al Hikmah bandar lampung

\begin{tabular}{|c|l|c|c|c|c|}
\hline No & \multicolumn{1}{|c|}{ Indikator } & \multicolumn{2}{|c|}{ Eksperimen } & \multicolumn{2}{c|}{ Kontrol } \\
\cline { 3 - 6 } & Pretest & Posttest & Pretest & Posttest \\
\hline 1. & $\begin{array}{l}\text { Memberi Penjelasan } \\
\text { Sederhana }\end{array}$ & $66 \%$ & $77 \%$ & $61 \%$ & $73 \%$ \\
\hline 2. & $\begin{array}{l}\text { Membangun } \\
\begin{array}{l}\text { Keterampi } \\
\text { lan Dasar }\end{array}\end{array}$ & $63 \%$ & $85 \%$ & $57 \%$ & $68 \%$ \\
\hline 3. & $\begin{array}{l}\text { Menyimpul } \\
\text { kan }\end{array}$ & $72 \%$ & $87 \%$ & $70 \%$ & $72 \%$ \\
\hline
\end{tabular}




\begin{tabular}{|c|l|c|c|c|c|}
\hline 4. & $\begin{array}{l}\text { Memberikan } \\
\text { penjelasan lebih } \\
\text { lanjut }\end{array}$ & $65 \%$ & $76 \%$ & $67 \%$ & $71 \%$ \\
\hline 5. & $\begin{array}{l}\text { Mengatur strategi } \\
\text { dan taktik }\end{array}$ & $57 \%$ & $81 \%$ & $54 \%$ & $65 \%$ \\
\hline & $\begin{array}{c}\text { Total } \\
\text { rata-rata }\end{array}$ & $\mathbf{6 5 \%}$ & $\mathbf{8 1 \%}$ & $\mathbf{6 2 \%}$ & $\mathbf{7 0 \%}$ \\
\hline
\end{tabular}

\section{Uji Prasyarat}

Sebelum dilakukan uji hipotesis terlebih dahulu melakukan uji prasyarat. Uji prasyarat dalam penelitian ini meliputi uji normalitas dan uji homogenitas.

\section{a. Uji Normalitas}

Uji normalitas dalam penelitian ini digunakan untuk mengetahui apakah data berdistribusi normal atau tidak. Adapun hasil uji normalitas dapat dilihat pada table 2 dan

Table 2. Hasil uji normalitas pretest

\begin{tabular}{|l|c|c|c|c|}
\hline \multirow{2}{*}{ Karakteristik } & \multicolumn{2}{|c|}{ Hasil Pretest } & \multirow{2}{*}{ Hasil } & \multirow{2}{*}{ Interpretasi } \\
\cline { 2 - 3 } & Kelas Eksperimen & $\begin{array}{c}\text { Kelas } \\
\text { Kontrol }\end{array}$ & \\
\hline $\mathrm{L}_{\text {hitung }}$ & 65,33 & 62,44 & \multirow{2}{*}{$\begin{array}{c}\mathrm{L}_{\text {hitung }} \\
<\end{array}$} & $\begin{array}{c}\text { Berdistribusi } \\
\text { Normal }\end{array}$ \\
\hline $\mathrm{L}_{\text {tabel }}$ & 0,170 & 0,170 & $\mathrm{~L}_{\text {tabel }}$ & \\
\hline $\mathrm{Db}$ & \multicolumn{2}{|c|}{52} & \multicolumn{2}{|c|}{$5 \%(0,05)$} \\
\hline Taraf Signifikansi & \multicolumn{3}{|c|}{} \\
\hline
\end{tabular}

Table 3. Hasil uji normalitas posttest

\begin{tabular}{|c|c|c|c|c|}
\hline \multirow[t]{2}{*}{ Karakteristik } & \multicolumn{2}{|c|}{$\begin{array}{r}\text { Hasil Pretest } \\
\end{array}$} & \multirow[b]{2}{*}{ Hasil } & \multirow[b]{2}{*}{$\begin{array}{c}\text { Interpretas } \\
\text { i }\end{array}$} \\
\hline & $\begin{array}{c}\text { Kelas } \\
\text { Eksperimen }\end{array}$ & Kelas Kontrol & & \\
\hline $\mathrm{L}_{\text {hitung }}$ & 81,92 & 70,37 & \multirow{3}{*}{$\begin{array}{c}\mathrm{L}_{\text {hitung }} \\
< \\
\mathrm{L}_{\text {tabel }}\end{array}$} & \multirow{3}{*}{$\begin{array}{c}\text { Berdistribus } \\
\text { i Normal }\end{array}$} \\
\hline $\mathrm{L}_{\text {tabel }}$ & 0,170 & 0,170 & & \\
\hline $\mathrm{Db}$ & & & & \\
\hline Taraf Signifikansi & \multicolumn{4}{|c|}{$5 \%(0,05)$} \\
\hline
\end{tabular}

a. Uji Homogenitas

Uji homogenitas dimaksudkan untuk memperlihatkan bahwa dua atau lebih kelompok sampel berasal dari populasi yang memiliki variansi yang sama. Adapun hasil uji homogenitas dapt dilihat di Tabel 4.

Tabel 4. Hasil Uji Homogenitas Pretest dan Posttest

\begin{tabular}{|c|c|c|c|c|}
\hline Karakteristik & Pretest & Posttest & Hasil & Interpretasi \\
\hline $\mathrm{F}_{\text {hitung }}$ & 1,85 & 1,43 & \multirow{3}{*}{$\begin{array}{l}\mathrm{L}_{\text {hitung }} \\
< \\
\mathrm{L}_{\text {tabel }}\end{array}$} & \multirow{3}{*}{ Homogen } \\
\hline $\mathrm{F}_{\text {tabel }}$ & 1,90 & 1,90 & & \\
\hline $\mathrm{Db}$ & & 52 & & \\
\hline $\begin{array}{l}\text { Taraf } \\
\text { Signifikansi }\end{array}$ & \multicolumn{4}{|c|}{$5 \%(0,05)$} \\
\hline
\end{tabular}

\section{a. Uji-t}

Hasil uji hipotesis yang menggunakan perhitungan rumus uji-t independent secara manual pada hasil kemampuan berpikir kritis peserta didik dapat dilihat pada Tabel 5 di bawah ini.

Table 5

Hasil Perhitungan Uji-t 


\begin{tabular}{|l|c|c|c|}
\hline \multicolumn{1}{|c|}{ Karakteristik } & Hasil Uji t & Hasil & Interpretasi \\
\cline { 1 - 2 } $\mathrm{t}_{\text {hitung }}$ & 7,80 & $\mathrm{t}_{\text {hitung }}$ & \\
\cline { 1 - 2 } $\mathrm{t}_{\text {tabel }}$ & 1,67 & $\mathrm{H}_{1}$ diterima \\
\cline { 1 - 2 } Db & 52 & $\mathrm{t}_{\text {tabel }}$ & \\
\cline { 1 - 3 } Taraf Signifikansi & \multicolumn{2}{|c|}{$5 \%(0,05)$} \\
\hline
\end{tabular}

\section{Pembahasan}

Berdasarkan tabel data hasil kemampuan berpikir kritis tersebut dapat dipahami bahwa masing- masing pada kelas eksperimen dan kontrol mengalami kenaikan, yang mana pada kelas eksperimen nilai rata-rata pretes nya $65 \%$ menjadi $81 \%$, sedangkan untuk kontrol rata-rata awal nya dari $62 \%$ menjadi $70 \%$. Namun ada perbedaan yaitu pada kelas eksperimen yang kemampuan awal berpikir kritisnya cukup dan setelah diberikan perlakuan model time token berbantu puzzle menjadi baik, sedangkan yang kelas kontrol mengalami kenaikan tapi masih sama- sama dalam katagori cukup. Dari hasil tersebut dapat dikatakan bahwa model time token berbantu puzzle dapat berpengaruh terhadap kemampuan berpikir kritis peserta didik.

Soal pretest dan posttest yang diberikan berupa soal uraian 10 soal masing-masing soal mencakup lima indikator berfikir kritis yaitu: 1) memberikan penjelasan sederhan; 2) membangun keterampilan dasar; 3) menyimpulkan; 4) memberikan penjelasan lebih lanjut; 5) mengatur strategi dan taktik. Dalam lima indikator tersebut terbagi dalam 10 sub indikator dimana setiap satu subindikator mewakili satu soal kemampuan berpikir kritis. Peningkatan hasil kemampuan berpikir kritis peserta didik dapat dilihat dari hasil tes akhir atau posttest yang dilakukan peserta didik kelas eksperimen dan kontrol setelah diberi perlakuan dengan model pembelajarn time token berbantu puzzle untuk kelas eksperimen dan model pembelajaran kooperatif media gambar pada kelas kontrol. Berikut perbandingan posttest antara kelas eksperimen dan kelas kontrol dalam tiap indikator berpikir kritis.

Berdasarkan grafik rata-rata skor indikator kemampuan berpikir kritis kelas eksperimen dan kontrol pada kegiatan posttest untuk setiap indikator diperoleh persentase hasil kemampuan berpikir kritis peserta didik memberikan penjelasan sederhana sebesar $77 \%$, membangun keterampilan dasar sebesar $85 \%$, menyimpulkan sebesar $87 \%$, memberikan penjelasan lebih lanjut $76 \%$, dan mengatur strategi dan taktik sebesar $81 \%$. Hasil persentase tersebut peserta didik yang menyimpulkan memperoleh nilai lebih tinggi, hal tersebut dikarenakan pada saat proses pembelajaran dengan adanya diskusi kelas antar peserta didik dalam kelompok, dan strategi peneliti untuk berinteraksi dengan peserta didik dengan memberikan fakta-fakta terkait Gelombang, dengan pertanyaan yang terbuka maka pesrta didik akan bertanya hal yang belum mereka tahu dan dapat mendorong peserta didik untuk berfikir kritis dalam menjelaskan secara sederhana apa yang sudah diketahui. Dengan begitu wawasan peserta didik akan tergali dengan sendirinya, peserta didik begitu aktif menjawab atau menjelaskan pertanyaan yang diberikan oleh pendidik atau peserta didik kelompok lainnya, 
sehingga mereka dapt membangun keterampilan dasar mereka hingga dapat menyimpulkan suatu fakta atau asumsi dengan tepat mengenai gelombang, seperti pada gambar 1 di bawah ini.

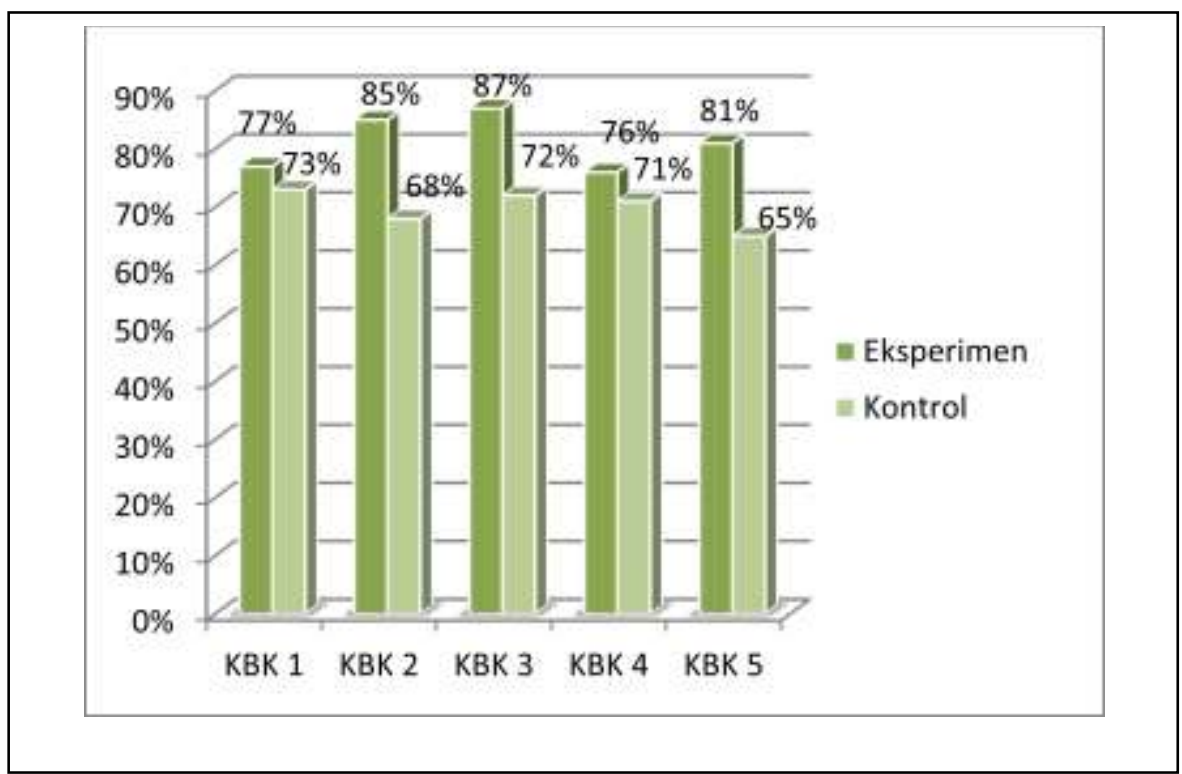

Gambar 1 . Rata-rata skor indikator kemampuan berpikir kritis kelas eksperimen dan kontrol pada kegiatan posttest untuk setiap indikator

Sedangkan peserta didik yang memberikan penjelasan lanjutan memperoleh nilai yang rendah, hal tersebut dikarenakan pada saat diskusi kelompok peserta didik masih banyak yang kesulitan untuk memahami konsep materi pelajaran, sehingga pada saat guru memberikan faktafakta terkait Gelombang peserta didik lebih banyak hanya diam dan kurang aktif pada saat proses pembelajaran, sehingga peserta didik hanya dapat menyebutkan dan menyimpulkan saja tanpa memberikan alasan yang tepat, karena berpikir kritis adalah berpikir bukan sekedar mengingat atau memahami suatu konsep, tetapi berpikir yang beralasan untuk memecahkan suatu masalah dan menekankan untuk membuat keputusan tentang apa yang harus dilakukan dan bisa dipercaya. Sebagaimana persentase capaian seseorang dikatakan sudah mampu berpikir kritis dengan katagori baik jika nilai persentase berpikir kritis mencapai 76\%-100\%.

Berdasarkan analisis data pengujian hpotesis dengan menggunakan uji-t independent diperoleh hasil $t_{\text {hitung }}=7,80$ sedangkan $t_{\text {tabel }}=1,67$ sehingga $t_{\text {hitung }}>t_{\text {tabel }}$ yaitu 7,80>1,67 maka hipotesis $\mathrm{H}_{0}$ ditolak dan $\mathrm{H}_{1}$ diterima, artinya ada pengaruh yang signifikan antara kelas yang menggunakan model time token berbantu puzzle dengan yang tidak menggunakan model time token berbantu puzzle. Hal ini menunjukan bahwa ada pengaruh yang signifikan menggunakan model time token berbantu puzzle terhadap kemampuan berpikir kritis peserta didik pada materi Gelombang.Hasil uji-t posttest terhadap $t_{\text {tabel }}$ dapat dilihat pada gambar 2 di bawah ini. 


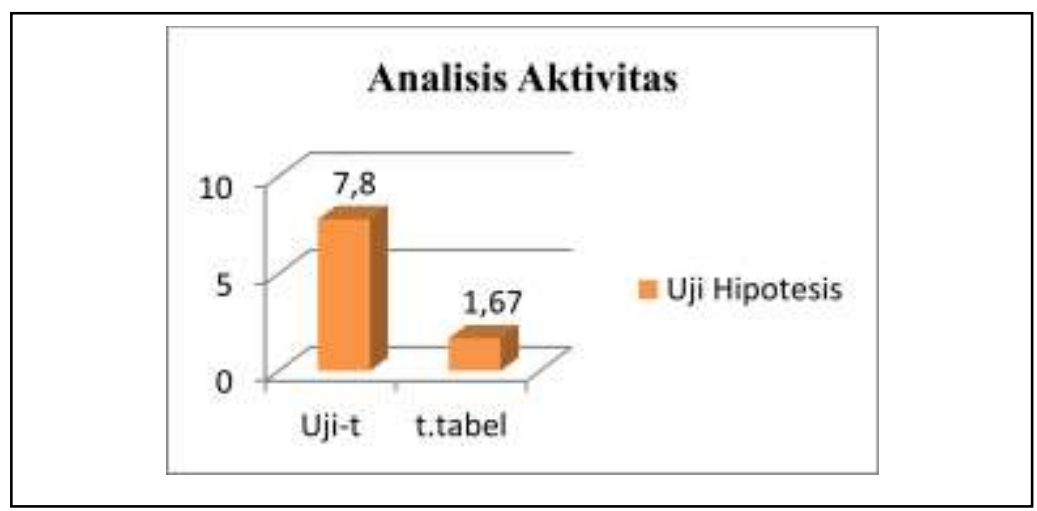

Gambar 2. Uji-t posttest terhadap $\mathrm{t}_{\text {tabel }}$

Berdasarkan gambar diatas diketahui bahwa rata-rata nilai peserta didik pada kelas yang pembelajarannya menggunakan model time token berbantu puzzle berbeda dengan kelas yang pembelajarannya tanpa menggunakan model time token berbantu puzzle . Hal ini menunjukan bahwa pembelajaran menggunakan model koopeartif tipe time token berbantu puzzle memberi pengaruh terhadap kemampuan berpikir kritis peserta didik (memberikan penjelasan sederhan, membangun keterampilan dasar, menyimpulkan, memberikan penjelasan lebih lanjut, mengatur strategi dan taktik). Hal tersebut dapat dilihat dari persentase nilai rata-rata pretest dan posttest peserta didik.

Pada kelas eksperimen penggunaan model kooperatif tipe time token berbantu puzzle memberikan efektifitas yang baik terhadap hasil kemampuan berpikir kritis peserta didik. Hal ini dikarenakan pada kelas eksperimen peserta didik lebih aktif dibandingkan dengan kelas kontrol disetiap tahap-tahap pembelajaran yang berlangsung ini dibuktikan dengan hasil kemampuan berpikir kritis.

Pada kelas eksperimen yang menggunakan model kooperatif tipe time token berbantu puzzle , saat proses pembelajaran peserta didik terlebih dahulu menyusun yang berisi gambar serta keterangan gambar untuk menjawab soal pada LKK (lembar kerja kelompok) yang telah tersedia. Tiap kelompok terdiri dari 56 peserta didik. disini adalah menyusun kepingan-kepingan gambar sehingga terbentuk suatu gambar yang utuh. Dengan media tersebut proses pembelajaran di kelas menjadi lebih menyenangkan dan peserta didik menjadi termotivasi dalam memahami konsep materi Gelombang.

Salah satu faktor yang mempengaruhi model pembelajaran kooperatif tipe time token berbantu puzzle terhadap kemampuan berpikir kritis peserta didik, yaitu peserta didik mendapatkan peran atau terlibat pada pembelajaran, karena setiap peserta didik diwajibkan untuk menggunakan kartu bicaranya sampai habis. Berdasarkan teori, model pembelajaran kooperatif tipe time token berbantu puzzle dapat mendorong peserta didik untuk meningkatkan inisiatif dan partisipasinya pada saat diskusi berlangsung. Sehingga peserta didik tidak mendominasi pembicaraan atau diam tak berbicara sama sekali. Dengan demikian peserta didik akan menjadi lebih aktif dalam kegiatan pembelajaran.

Model pembelajaran kooperatif tipe time token berbantu puzzle dapat melatih peserta didik untuk mengungkapkan pendapatnya, mampu menumbuhkan kebiasaan pada peserta didik untuk saling mendengarkan, berbagi, memberikan masukan, dan keterbukaan terhadap kritik. 
Selain itu, model pembelajaran ini dapat mengajarkan peserta didik untuk menghargai pendapat dari peserta didik lainnya. Dengan adanya membuat peserta didik tertarik untuk menyelesaikan LKK dengan baik dan pembelajaran menjadi lebih bervariatif, peserta didik lebih antuasias dan semangat untuk belajar sehingga memacu keaktifan peserta didik.

\section{Kesimpulan}

Berdasarkan hasil penelitian dan pembahasan tentang model pembelajaran kooperatif tipe time token berbantu puzzle terhadap kemampuan berpikir kritis dapat disimpulkan bahwa ada pengaruh yang signifikan antara penggunaan model pembelajaran kooperatif tipe time token berbantu puzzle terhadap kemampuan berpikir kritis peserta didik kelas kelas $\mathrm{X}$ semester genap pada materi Gelombang di MA Al Hikmah Bandar Lampung Tahun Pelajaran 2014/2015.

\section{DAFTAR PUSTAKA}

Djaali. Psikologi Pendidikan. Jakarta: Bumi Aksara, 2008.

Hamzah,B.Uno.Perencanaan pembelajaran. Jakarta: PT Bumi Aksara, 2011.
Huda, Miftahul. Model-Model Pengajaran dan Pembelajaran. Yogyakarta: Pustaka Pelajar, 2013.

Johnson, Elaine B. CTL (Contextual Teaching \& Learning). Bandung: Kaifa Learning, 2014.

Park E.Y dan Park Y.H. A Hierarchical Interface Design of a Puzzle Game for Elementary Education. International Journal of $u$ - and $e$ Service, Science and Technology, Vol. 3, No. 2, h.43-49, 2010. ( On line), tersedia di : (http://www.SciRP.org/journal/ce). (22 Januari 2015).

Ristiasari Tia, Priyono Bambang, Sukaesih

Sri. Model Pembelajaran Problem Solving Dengan Mind Mapping Terhadap Kemampuan Berpikir Kritis Siswa. Unnes Journal of Biology Education. 2012. (Online), tersedia di: http://journal.unnes.ac.id/sju/index.p hp/ujbe/article/view/1498 Januari 2015).

Shoimin, Aris. 68 Model Pembelajaran Inovatif Dalam Kurikulum 2013. Yogyakarta: Ar-ruzz Media, 2014. 